DOI: $10.22616 /$ j.balticsurveying.2018.005

\title{
ASSESSMENT OF THE ROLE OF FOREST LAND IN SAMARA REGION AS ENVIRONMENTAL PROTECTION AND LAND DEGRADATION PREVENTION FACTOR
}

\author{
Gabibulla Khasaev ${ }^{1}$, Alexandr Vlasov ${ }^{1}$, \\ Dariya Vasilieva $^{1}$, Velta Parsova ${ }^{2}$ \\ ${ }^{1}$ Samara State University of Economics, \\ ${ }^{2}$ Latvia University of Life Sciences and Technologies
}

\begin{abstract}
The article discusses the current state of forest land, the history of formation of large tracts of forest in the Samara region and analyses some of the results of implementation of target programs to improve the forest cover in the region under the Kyoto Protocol. This program was designed for the period from 2006 to 2015, but in 2009 was discontinued. However, large segment of assets was allocated and a number of works was carried out. Currently the objectives of the programme to increase the forest cover in the territory of Samara region through the creation of tracts of forest are not achieved. Tree and shrub plantations play an important role in reducing the activity of processes of erosion, prevent degradation and desertification. Therefore, the problem of increasing forest cover, especially in the steppe zone of the region, to the level of the preindustrial era remains relevant and requires science-based measures for their solution.
\end{abstract}

Key words: environmental management, forest cover, forest land, forests, tract of forest

\section{Introduction}

According to the FAO Global Forest Resources Assessment, the Russian Federation is the world leader in total area of forests, since it has more than $20 \%$ of the world's forests. The total area of the forest land is about $69 \%$ of the total land area in Russia (together with inland waters), while $78 \%$ of forest area of Russia are located in its Asian part and 22\% - in the European-Ural part.

In general, there is a positive dynamics of the total forest area in Russia. Since 1956 the area of forestland has increased by $20 \%$ and by the end of 2016 it amounted to 794.5 million hectares. The increase of area of forest land mainly occurred due to overgrowing of agricultural and reserve land with lowvalue leaf trees (willow, grey alder, birch) species. The non-forested area in Russia has decreased from 1956 to 40 million hectares. Perhaps this is also related to global warming, as the boreal zone has reduced the period of natural forest regeneration by 1-2 years, the vegetation period has increased by 10-15 days, and the boundary of forest land has progressed significantly to the north (by 50-100 $\mathrm{km}$, especially on the banks and valleys of rivers) (State report..., 2017). Forest land of the territory of the Russia, i.e. the ratio of the area covered by forest vegetation to the total area of the country has not changed and is $46 \%$. On the territory of the country, forests are unevenly distributed, depending on climatic and anthropogenic factors. The highest proportion of forest land is located in Irkutsk region (83\%), Primorsky Krai (77\%), Kostroma region (74\%), Komi Republic (73\%). Low proportion of forest cover is recorded in the Republic of Kalmykia (0.2\%), Stavropol Krai, Astrakhan and Rostov region (about 2\%).

All the forest stock land in Russia is owned by the state and cannot be transferred to private ownership. Forests are divided into three groups:

- I group - protective (water protection, protective strips, anti-erosion forests, etc.) forests;

- II group - forests in urban area (with high population density), having protective and limited production significance;

- III group - forests in wooded areas, having production significance (Forest Code, 2006).

The land of I group can be leased for the placement of recreational facilities (recreation centres, tourist bases, etc.). There it is forbidden to cut forests, build buildings with a foundation and require strict compliance with environmental standards (Vlasov A.G., Voronin V.V., Vasilieva D.I., 2013). 
Forests play an important role as an environmental factor, as well as a source of valuable natural resources. The ability of natural systems to absorb greenhouse gases is limited. Therefore, the ever increasing anthropogenic emissions of these gases lead to a steady increase in their concentration in the atmosphere and to global warming (Melekhov I.S., 1989; Pchelin V.I., 2007).

According to UN FAO (GULR 2015) estimates, carbon reserves in the world are about 360 billion tons, of which $14 \%$ are concentrated in the forests of Russia. The high role of forest vegetation in a warming climate is a global environmental problem, especially relevant for the territory of Russia: if global warming has a speed of about $0.18^{\circ} \mathrm{C}$ for every 10 years, then Russia warms 2.5 times faster $0.45^{\circ} \mathrm{C}$ over 10 years (State report..., 2017).

\section{Methodology of research and materials}

In addition to the environment-forming function, forests are important for reducing the rate of destruction of land by processes of water and wind erosion. This problem is acute in the territory of low-forest or forestless steppe regions, to which the Samara region belongs (Atlas..., 2018). Practically complete inconsistency of the land in the steppe zone led to a catastrophic increase in the activity of erosion processes. The present state and changes in the land of forest stock of Samara region was studied. The materials of actual state reports on the status and use of land of the Russian Federation and the Samara region, reports of relevant ministries, the results of program for increasing the forest cover in the Samara region, which took place during the implementation of the activities of the Kyoto Protocol were analysed (Report..., 2016; State report..., 2007; State registration..., 2008; Consolidated project..., 1985; Strategy..., 2006, Concept ..., 2003 ).

\section{Discussions and results}

In the Samara region forests take up about 757 thousand hectares or 13\% of the total region's area, therefore it belongs to the regions with low forest cover (Averina L.V., Voronin V.V., Vlasov A.G., Vasilieva D.I., 2014). All forests of the Samara region are classified as protective. Especially valuable forests (national parks, nature monuments, state forest belts) occupy $20 \%$ of the forest area in the region; forests that perform recreational, sanitary and hygienic functions (green areas of cities) - 19\%; restricted forest areas along rivers and roads - 14\%; forests, performing mainly field-protective functions - 47\% (Voronin V.V., Vlasov A.G., Vasilieva D.I., 2013) (Fig. 1). 


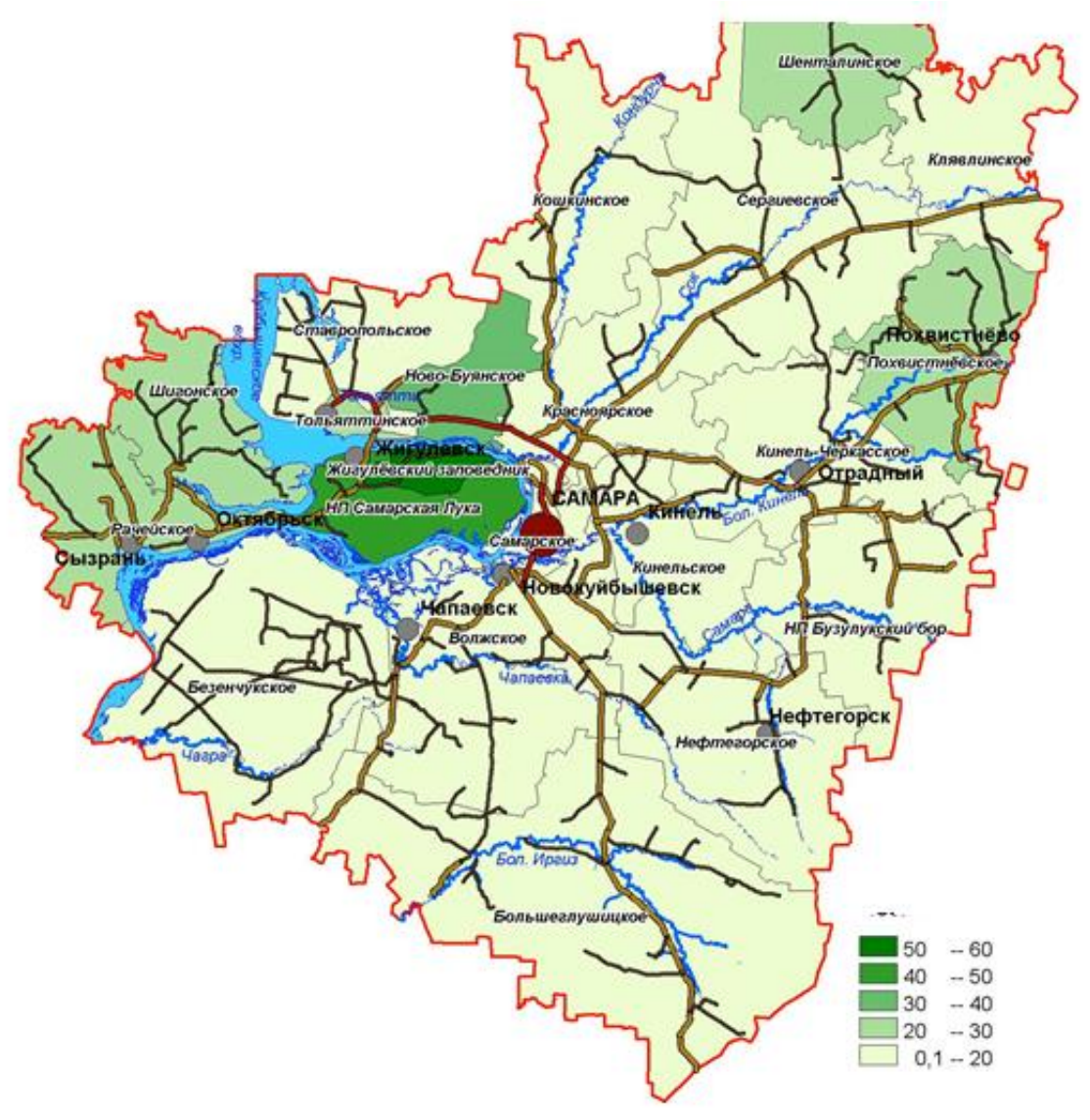

Fig. 1. Extent of afforestation in the Samara region

The territory occupied by forests in the Samara region includes:

- forests located on the forest stock land - 583 thousand hectares;

- forests located on the land of specially protected natural objects - 141 thousand hectares (Buzuluksky Bor, Samarskaya Luka National Park, Zhigulevsky Reserve);

- urban forests - 10 thousand hectares;

- forests of agricultural enterprises - 24 thousand hectares

The forests are distributed unevenly in the steppe and forest-steppe zones of the region (Kupriyanov N.V., Veretennikov S.S., Shishov V.V., 1995). The greatest forest cover (about 30\%) is observed on the right-bank forest-steppe part. On the Zhiguli Hills the forests cover about 70\%, on the left-bank forest-steppe zone of the region, located north of the river Samara the forest cover is lower - about $20 \%$. Forests here are located on the watersheds, floodplain forests are also widespread. The smallest forest area is located on the zones of southern and dry steppe of the Samara region (Alekseevsky, Bolsheglushitsky, Bolshechernigovsky, Krasnoarmeisky, Pestravsky districts), where the forest cover is insignificant and makes about 2\% (Melekhov I.S. (1989); State registration... (2008); Consolidated project... (1985). There are no significant tracts of forest, small forest areas are found only in floodplains of rivers.

According to the order of the Ministry of Agriculture of Russia No. 37 of 04.02 .2009 "On approval of the list of forest areas of the Russian Federation", the forest stock of the Samara Region belongs to the forest-steppe zone (18 municipal districts) and to the steppe zone (9 municipal districts) of the European part of Russia (Fig. 2). 


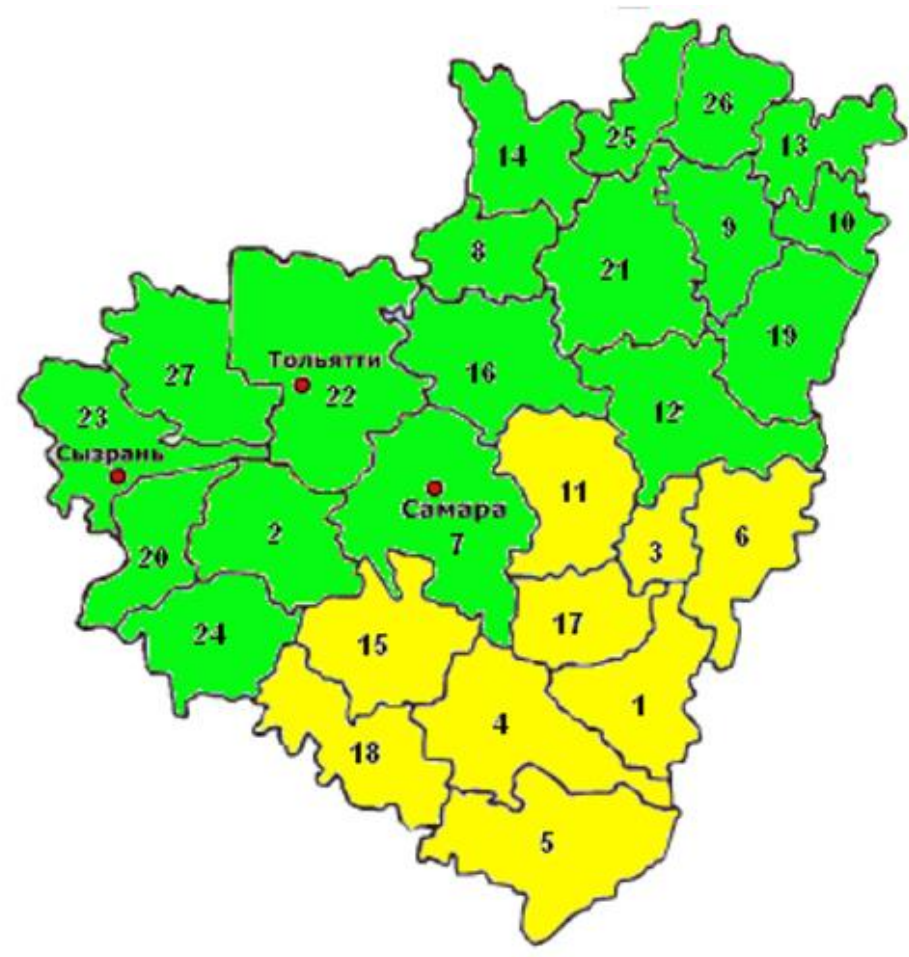

forest-steppe zone steppe zone

Fig. 2. Forest zoning of the Samara region

Prevailing tree species in forests of Samara region are - oak (27\%), linden (20\%), aspen (19\%), pine (14\%), birch (9\%). Other species include maple, ash, elm, poplar, etc. The age structure of forests was distributed as follows: young - 23\%; middle-aged - 47\%; ripen-aged - 13\%; ripe-aged - $17 \%$. The total stock of forest stands was 57 million $\mathrm{m}^{3}$, including 9 million $\mathrm{m}^{3}$ of mature and over-mature. The overall average increase is about 2 million $\mathrm{m}^{3}$. The average reserve of mature and over-mature trees per 1 ha is $177 \mathrm{~m}^{3}$, of which coniferous $-312 \mathrm{~m}^{3}$, hard forest $-137 \mathrm{~m}^{3}$, soft-leaved trees $-215 \mathrm{~m}^{3}$.

In Samara region compact tracts of forest are located in the right bank of Volga river on the Zhiguli Hill and in the northern part of the region - in the forestry companies (former leshozes). On the banks of the river Volga, Samara, the rivers Big and Small Kinel, Soka, Kondurchi as narrow strips expand floodplain forests.

On the border with the Orenburg region is the widely known Buzuluksky Bor (now - a national park, a federal protected area). The total area of this national park is 112 thousand hectares, including 54 thousand ha in the Samara region. In addition, in the Samara region there are two more protected areas of federal importance - the Zhigulevsky State Nature Reserve (23 thousand hectares) and the national nature park "Samarskaya Luka" (128 thousand hectares).

Attempts to increase the forest cover of the territory in the Samara region were undertaken at the end of the XIX century (Uspensky E.I., 1987). This was done in order to reduce the processes of wind erosion, because forest belts reduce the wind speed. Therefore, the protective forest belts were planted taking into account the prevailing wind direction. After the creation of forest belts in the territory of the region, the number of dust storms has decreased and the land hazard by wind erosion has decreased. In the period from 1889 to 1906 under supervision of scientist N.Genko in Samara province in Volga river valley about 17 protective forest belts with total area more than 8 thousand hectares were arranged.

They represented forest belts with a width of $639 \mathrm{~m}$, located in broken lines of various lengths (up to $25 \mathrm{~km}$ ) along the most elevated parts of the watersheds of the tributaries of the Volga - the Sok and Padovki rivers (Shilan stripes); the rivers of Samara and Chapaevka (Dubovo-Umet and Teplovskie stripes) and the Chapaevka and Chagry rivers (the Kamyshinskaya, Bezenchuk and Vladimirsky stripes). At the present, these forest belts have been preserved in good condition with a diverse forest stands, they are capable for natural renewal. The second generation of forest has grown as a result of 
self-seeding. They represent a valuable result of the past steppe afforestation in the Trans-Volga region and nowdays are protected areas of regional importance.

In 1894-1897 under supervision of agronomist Grodsky forest belts were arranged on the area of more than 60 hectares, which also today belong to the regional protected areas (Zagreev V.V., Sukhikh V.I., Shvidenko A.Z. et al., 1992).

An important stage for the development of forest amelioration, solving problems of combating drought and erosion in agro-nature use in the Samara region was the creation in 1930 of forest amelioration station in the Middle Volga zone, which since 1936 became known as the Volga agroforestry experimental station (hereinafter - AGLOS) with subordination to the All-Union Scientific agroforestry research institute (Zakamsky V.A., Andreev N.V., 2005). The zone of activity of AGLOS was an extensive region of the Middle Volga region - steppe zone with predominantly chernozem soils. The main tasks of AGLOS were:

- improving the microclimate on the fields in the system of forest belts, increasing yields and sustainability of crops;

- development of a complex of anti-erosion measures for effective control of erosion processes and productive use of eroded land;

- development of rational ways of conducting business in forest cultures and studying the water protection and protective role of forest plantations;

- introduction and acclimatization into newly created plantations of most valuable, productive and resistant forest species;

- economic justification of agroforestry and forestry measures, development of the most progressive forms and methods of organization of work.

In the post-war period the USSR developed and implemented a plan for the creation of protective forest plantations, the introduction of grass-field crop rotations, the construction of ponds and reservoirs to ensure high yields in the steppe and forest-steppe regions of the European part of the USSR. In the territory of the Samara (former Kuybyshev) region for improvement of the state of the land in 1949-1965 the program "Protective stands on all areas of the region" was embodied. According to this plan in Samara region on ravines, beams and watersheds, on sands and in the state forest stock 244 thousand hectares of forests were planted, including:

- 57 thousand hectares on the land of state forest stock;

- 15 thousand hectares on the land of collective farms;

- 32 thousand hectares on the land of state agriculture enterprises.

In each state forest and agriculture enterprise, and collective farm, the work was carried out to harvest forest seeds, cultivate planting material and create protective forest plantations. In addition, in 19491953, the fixation and afforestation of mobile sands was carried out. The role of forest vegetation is very important in the absorption of $\mathrm{CO}_{2}$, release of $\mathrm{O}_{2}$, impact on the climate, reduction of wind and water erosion, etc. Currently, one of the global environmental problems is the warming of the climate, associated with an increase of concentration of $\mathrm{CO}_{2}$ and other greenhouse gases in the atmosphere. To solve this problem, Framework Convention on Climate Change of United Nations was adopted, which set the goal of stabilizing the concentration of greenhouse gases in the atmosphere at a level that would prevent a dangerous anthropogenic impact on the climate system. The Kyoto Protocol became the first step towards the implementation of the greenhouse gas stabilization program in the atmosphere. In 2004, it was ratified by Russia, and a market-based approach to solving environmental problems began - the preparation for trading greenhouse gas emissions with the provision of funds for growing forests to absorb carbon dioxide (Voronin V.V., Vlasov A.G., Vasilieva D.I., Most E.S., 2013, 2014). After inclusion in the Kyoto Protocol the law of the Samara Region No. 83-GD of 11.07.2006 was adopted. This law approved the target program "Increase of forest cover within the framework of implementation of the goals of Kyoto Protocol, protection of forests in the Samara region for 2006 - 2015" (hereinafter - the Program). The objectives of the Program were as follows:

- improving the environmental situation in the Samara region;

- increase of forest areas of the region in the framework of the implementation of the goals of the Kyoto Protocol to reduce the greenhouse effect through deposition from the atmosphere of carbon dioxide and the accumulation of carbon in the ecosystem; 
- creation of specially protected natural areas of regional importance;

- increase of forest areas by $20 \%$ and increase of forest cover of the region to $15 \%$;

- ensuring reliable and effective protection of soils from erosion.

The achievement of these goals was facilitated by the solution of a number of problems:

- conservation and enhancement of forest plantations in the Samara region;

- afforestation on an area of 30 thousand hectares;

- creation of protective forest plantations on the area of 110 thousand hectares;

- creation of a complex of protective forest belts;

- restoration of protective functions of existing forest belts.

The program was supposed to create protective forest facilities in the southern and south-eastern parts of the Samara region, in particular the "forest bridge" Buzuluksky Bor - Kazakhstan of long-lasting, valuable tree species, designed to become a barrier for dry winds, to protect the land from adverse natural factors. This afforestation was proposed to be implemented through the creation of specially protected natural areas of regional importance, which are of great environmental and scientific importance, on the land outside the forest stock and unfit for agricultural production.

Within the framework of the Program, it was planned to create various types of protective forest plantations: strips, in the form of pins, curtains, tracts, and plantations from fast-growing tree species, which should significantly enhance the aesthetic appeal of landscapes in the Samara region, and also provide the population with timber and by-products of the forest. The implementation of the complex of protective forest plantations during the Program would prevent the weakening and drying up of existing and newly created protective plantations. It is necessary to create water conservation plantations that absorb a large amount of filtration water, transfer the surface overflow into the subsoil, reduce soil erosion from flat flushing with flood waters and summer showers, protect the banks from wave erosion.

At present, it is possible to sum up some results of the implementation of the first stages of this Program. Its unconditional importance for solving both global and regional environmental problems It should be noted. The increase of forest cover in the Samara region to the level of the end of the 18th and early $19^{\text {th }}$ centuries, when during the period of general surveying in 1786-1835 about $28 \%$ of the territory was occupied by forests would lead to a significant increase in the absorption of $\mathrm{CO}_{2}$ from the atmosphere. In addition, forests contribute in the accumulation of moisture in the soil, decrease in surface water overflow and increase in the underground water, which leads to the accumulation of groundwater in the soil and to decrease the leaching of the soil, to increase of soil fertility, etc.

Analysis of the current state of the plantations planted in 2006-2008 in the framework of the Program shows their current unsatisfactory condition. Planted seedlings are not able to take root and the plans to create forest stands from them in the form of protective forest belts, afforestation of the banks of small rivers did not take place. A possible reason was the absence of a scientifically grounded approach to the problem of providing the territory of the Samara region with planting material, in particular, unadapted seedlings from the northern regions of the European territory of the country (Tatarstan, Perm Krai), which are unsuitable for planting in the steppe zone of the Samara region. At the same time in the territory of the Samara region, there are their own forest seed plantations and nurseries, including coniferous species (Pinus sylvestris). The experience of AGLOS demonstrates that one of the most frequent reasons for the failed efforts to create forest plantations in the steppe is the wrong choice of breeds for their creation. Forests have long associated the productivity and viability of forest plantations with geographical origin and hereditary properties of seeds. It is practically impossible to grow forest plantations in an arid steppe zone from the planting material of the forest zone. Adapted to the steppe conditions are, for example, pine forests growing here, which are a valuable seed base for steppe afforestation. In the steppe regions of the country, plants that are resistant to unfavorable conditions of the steppe, characterized by a more economical use of moisture, salt tolerance, capable of effectively using a huge stream of solar radiation, high summer temperatures, strong wind and other unfavourable factors, should be selected for the cultivation of protective forest plantations. Another important reason for failures is incorrect agricultural technology in creating of protective forest plantations. Shortcomings and mistakes in agrotechnics usually took place due to undeep plowing of the soil (by $20-22 \mathrm{~cm}$ ), application of spring plowing instead of the 
recommended fallows, incorrect selection of plant species without considering the compliance of their biological properties to forest-growing conditions, the use of bad quality planting material, insufficient care about conditions of soil. Lack of care for young plants, overgrowing of fields by weeds, which take away the moisture necessary for young trees, lead to their rapid extinction.

\section{Conclusions and proposals}

The target program "Increase of forest cover within the framework of the implementation of the goals of Kyoto Protocol, protection of forests in the Samara region for 2006 - 2015", adopted in 2006, was aimed at very important measures of environmental importance. But the analysis of the results of the implementation of this program shows that the allocated financial resources did not reach their goal, since the planting material for creating the plantations proved to be unviable, unsuited to the climatic and soil conditions of the steppe zone.

However, it is advisable to continue the activities of the Program taking into account soil and climatic conditions and using adapted planting material, which will ensure effective growth of plantations.

In order to achieve optimal forest cover in the Samara region, it is necessary to increase the amount of forest planting, using for this purpose the existing land reserve - ravines, river banks and various inconveniences.

The processes of wind and water erosion are widespread in the territory of the Samara region, the total area of eroded land exceeds 1 million hectares, of which heavily eroded land occupies 360 thousand hectares or $7 \%$ of the territory of the region.

The average annual flushing of the soil is $3-5 \mathrm{~m}^{3}$ per hectare, the annual losses of highly humus fine soil reach 5-8 million tons, while contamination of small rivers, ponds and reservoirs occur.

Forest plantations play an important role in reducing the activity of erosion processes, preventing land degradation and desertification, so increasing the forest cover in the Samara region is an important and urgent task.

\section{References}

1. State report "On the state and on the protection of the environment of the Russian Federation in 2016". Moscow: Ministry of Nature of Russia, NIA-Nature. 2017. 760 p.

2. Forest Code of the Russian Federation (Federal Law of December 4, 2006 No. 200-FZ). Moscow. 2007. 55 p.

3. Vlasov A.G., Voronin V.V., Vasilieva D.I. (2013) Legislative base of land and property complex. Problems of regional ecology, Volume 4, p. 117-121.

4. Melekhov I.S. (1989) Forest Science. Moscow. 302 p.

5. Pchelin V.I. (2007) Dendrology. Yoshkar-Ola. 520 p.

6. Atlas of intact forest landscapes of Russia. http://www.forest.ru/eng/ publications / intact. (2018)

7. Report on the state and use of land in the Samara region in 2015. Samara, 2016. 88 p.

8. State report on the state of the environment in the Samara region in 2006. Issue. 17. Samara. 2007. $325 \mathrm{p}$.

9. State registration of the forest fund of the Samara Region as of 01.01.2008. Samara. 2008. 256 p.

10. Consolidated project of the organization and development of forestry in the Kuibyshev region of management of the Ministry of Forestry of the Russian Federation, vol.1, book 1. Explanatory note on forest management materials 1983-1984. Ministry of Forestry of the Russian Federation. 1985. 395 p.

11. Strategy of social and economic development of the Samara region for the period until 2020. Samara.Samara Region Government. 2006. 235 p.

12. Concept of forestry development for 2003-2010. Moscow. 2003. 22 p.

13. Averina L.V., Voronin V.V., Vlasov A.G., Vasilieva D.I. (2014) Lands with special legal regime of use problems and ways of their solution. Problems of regional ecology, Volume 5, p.223 -228.

14. Voronin V.V., Vlasov A.G., Vasilieva D.I. (2013) Structure and assessment of the quality of lands in the Samara region. Problems of regional ecology, Volume 4. p. 109-116.

15. Kupriyanov N.V., Veretennikov S.S., Shishov V.V. (1995) Forests and forestry in the Samara Region. Nizhny Novgorod.- 349 p.

16. Uspensky E.I. (1987) Forest regeneration process under the canopy of small-leaved species of the Middle Volga region. Lesnoi journal. Volume 3, p. 116-118.

17. Zagreev V.V., Sukhikh V.I., Shvidenko A.Z. et al. (1992) Vsesouznye Norms for Forest Inventory. 495 p.

18. Zakamsky V.A., Andreev N.V.(2005) Recreational forestry. Yoshkar-Ola. 128 p.

19. Voronin V.V., Vlasov A.G., Vasilieva D.I., Most E.S. (2013) Ecological condition and quality of lands in the Samara region // Ecology of urbanized territories. Volume 4, p. 76-86. 
20. Voronin V.V., Vlasov A.G., Vasilieva D.I., Most E.S. (2014) The basic framework of territorial development // Ecology of urbanized territories. Volume 2, p. 41-49.

\section{Information about authors}

Habibulla Khasaev. Doctor of Economic Sciences, Prof., Rector of Samara State University of Economics. Address: Russia, 443090, Samara, Soviet Army street 141, of Latvia University of Life Sciences and Technologies. Address: 19, Akademijas str., Jelgava, LV-3001, phone +7 (846)-933-88-88, e-mail: rector@sseu.ru

Alexander Vlasov. PhD, Head of the Department of Land management and cadastre of Samara State University of Economics. Address: Russia, 443090, Samara, Soviet Army street 141, of Latvia University of Life Sciences and Technologies. Address: 19, Akademijas str., Jelgava, LV-3001, phone +7(937) 799-08-86, e-mail: vasilievadi@mail.ru

Darya Vasilieva. PhD, Associate Professor of the Department of Land management and cadastre of Samara State University of Economics. Address: Russia, 443090, Samara, Soviet Army street 141, of Latvia University of Life Sciences and Technologies. Address: 19, Akademijas str., Jelgava, LV-3001, phone +7(927) 200-30-78, e-mail: vasilievadi@mail.ru

Velta Parsova. Dr.oec., professor, Department of Land Management and Geodesy of Latvia University of Life Sciences and Technologies. Address: 19, Akademijas str., Jelgava, LV-3001, phone: +371 29118285, e-mail: velta@parsova.lv 